\title{
Development of Causal Model of Sustainable Hospital Supply Chain Management Using the Intuitionistic Fuzzy Cognitive Map (IFCM) Method
}

\author{
Seyed Habibollah Mirghafoori ${ }^{1}$ (D), Ali Morovati Sharifabadi ${ }^{1}$ (D), Salim Karimi Takalo ${ }^{2}$ (D) \\ ${ }^{1} Y a z d$ University (Islamic Republic of Iran) \\ ${ }^{2}$ Management Faculty of vali-E-Asr University (Islamic Republic of Iran) \\ mirghafoori@yazd.ac.ir,alimorovati@yazd.ac.ir,s.karimi@vru.ac.ir
}

Received: November 2017

Accepted: May 2018

\begin{abstract}
:
Purpose: Service industry is a massive sector accounting for about two-thirds of GDP of developed economies and is the field of an intensive competition between service companies and their supply chains. As a result, service supply chain management has become a subject of growing interest to researchers and business analysts. Healthcare industry is among the largest service industries with the highest potential for improvement in sustainability performance. The purpose of this study was to identify the concepts influencing the sustainability of hospital supply chain and provide a causal model for sustainable supply chain of hospital service. two aspects of contribution are identified for this research.
\end{abstract}

Design/methodology/approach: In this study, concepts that influence the sustainability of a hospital service supply chain were identified by in-depth interviewing of 18 experts in hospitals of Kerman, Iran. Delphi method was used to reorganize the initial concepts into 15 concepts, Thus, a framework for sustainable supply chain of the hospital is proposed in the present study. This is the first contribution of this study.

The second contribution is using the intuitive fuzzy cognitive map method for the relationship between extracted concepts.

Findings: Delphi method was used to reorganize 68 initial concepts into 15 concepts Contains: demand management, resource and capacity management, customer relationship management, supplier relationship management, service management, information management, financial performance management, Attention to the environment, contamination, energy consumption, legal requirements, employees, community and stakeholders, social accountability and business ethics. The results indicate that service delivery management is highly central among other concepts.

Originality/value: with focusing on concepts such as service management, and capacity and resources management, The sustainability of the hospital supply chain can be improved.

Keywords: service supply chain, sustainable supply chain management, Delphi method, hospital, intuitionistic fuzzy cognitive map

\section{To cite this article:}

Mirghafoori, S.H., Sharifabadi, A.M., \& Takalo, S.K. (2018). Development of causal model of sustainable hospital supply chain management using the Intuitionistic Fuzzy Cognitive Map (IFCM) Method. Journal of Industrial Engineering and Management, 11(3), 588-605. https://doi.org/10.3926/jiem.2517 


\section{Introduction}

Supply chain management (SCM) has long been a subject of interest to researchers. In today's economy, competition is no longer between companies, but rather between their supply chains (Hult, Ketchen \& Arrfelt, 2007). Supply chain is a dynamic process involving continuous flow of materials, financial resources, and information across functional areas and within and between the chain members, i.e. supply, production, and distribution (Ahi \& Searcy, 2013). Nowadays, companies have to ensure that all processes of business, from acquisition of raw materials to delivery of final products, are systematically integrated. This goal can be achieved by the use of SCM as means of integrated control over the flow of materials, goods, money, and information (Angerhofer \& Angelides, 2000). SCM consists of all functions that are directly or indirectly involved in satisfying the customers' demands, and include manufacturers and suppliers, as well as distributors, warehouses, and retailers (Ahi \& Searcy, 2013). There have been many studies on SCM, not only at tactical and operational levels, but also at strategic level (Chang \& Harris, 2001; Surana, Kumara, Greaves \& Raghavan, 2005; Huang, Lau \& Mak, 2003; Gunasekaran, Patel \& McGaughey, 2004), which many experts believe to be the most important aspect of this field (Guillén, 2005). In recent decades, growing public attention to issues such as energy prices, resource constraints, climate change, and social responsibility of businesses, particularly in regard to greenhouse gas emissions and quality of life has led to advent of a new revision of SCM called sustainable supply chain management (SSCM) (Carter \& Roger, 2008; Kleindorfer, Singhal \& Wassenhove 2005; Seuring \& Muller, 2008; Teuteberg \& Wittstruck, 2010; Brandenburg, Govindan, Sarkis \& Seuring, 2015; Ahi \& Searcy, 2015). SSCM is an extension of traditional SCM to include environmental, social, ethical objectives in addition to classic economic goals (Wittstruck \& Teuteberg, 2011). In the presence of strict environmental regulations and high public awareness about sustainability issues, many companies are now showing increasing attention to their sustainability performance and are attempting to incorporate sustainability objectives into their supply chain procedures (Zailani, Jeyaraman, Vengadasan \& Premkumar, 2012).

Review of SCM literature reveals that researches in this field are mostly concentrated on the supply chain issues of manufacturing sector (Ellram, Tate \& Billington, 2004; Sundarakani, De Souza, Goh, Wagner \& Manikandan, 2010; Cucek, Klemeš \& Kravanja, 2012; Gaussin, Hu, Abolghasem, Basu, Shankar \& Bidanda, 2013; Neves \& Leal, 2010; Mayyas, Qattawi, Omar \& Shan, 2012) and pay limited attention to the problems of service industries, which now constitutes a major portion of many developed and developing economies (Cho, Lee, Ahn \& Hwang, 2012). For example, in a developed country such as the United States, in 2010, service sector accounted for $84 \%$ of privatesector employment and $82 \%$ of private-sector gross domestic product (Haksever \& Render, 2013). This sector also plays a major role in economies of developing countries such as Iran, where, in 2013, services accounted for 47\% of employment and 50\% of gross domestic product (Iranian Statistics Center, 2014).

Despite the importance of service sector and its growing contribution to the world economy (Van Ark, Mahony \& Timmer, 2008), there are very few studies on the SCM in service sector, mainly because of inherent difficulties in developing a standard supply chain model for diverse and complex business processes of this sector (Sampson \& Froehle, 2006; Hussain, Khan \& Al-Aomar, 2015). For service sector, SCM involves integrated management of information, processes, and resources across the service supply chain with the objective of efficient provision of services to customers (Lin, Shi \& Zhou, 2010).

Healthcare industry is among the largest service industries with the highest potential for improvement in sustainability performance (Truffer, 2010). This is because healthcare industry is typically more energy intensive than other services, produces a significant amount of hazardous waste, has a high social impact (since it is labor intensive and employs more people than other services), and is tasked with serving patients and improving community health, which have extensive sustainability implications (Chung \& Meltzer, 2009).

Given the broad range of services provided in healthcare sector (curative care, preventive care, rehabilitative care, palliative care, etc.), this study is focused on the largest concentrated unit of organization in this field, i.e. hospital. There are few studies on the supply chain of the hospital; these studies focus on specific areas such as patient satisfaction, waste management, waiting time, and cost management. One level of supply chain is mainly considered in these studies. Literature review showed no comprehensive conceptual framework for a sustainable supply chain has been so far proposed in these studies (see Section 2.3.). Therefore, a conceptual framework of the 
sustainable supply chain of the hospital was first introduced in this study by identifying the effective concepts of the supply chain of the hospital. Moreover, a causal model of the relationship between these concepts is presented. A cognitive map method in an intuitive fuzzy environment has been used in order to design the causal model. Given that the cognitive map shows the relationships in form of 1 and 0 , it cannot illustrate the causal relationships in the real world, which is much more complicated. The intuitive fuzzy sets proposed by Etanassu are an appropriate tool for describing vague and inaccurate information. If this intuitive fuzzy set is combined with the cognitive mapping method, it will eliminate the disadvantages of cognitive mapping and show the causal relationships with their weights. This was a motivation for designing the causal model using the cognitive map method in an intuitive fuzzy environment in the present study.

\section{Literature Review}

\subsection{Service Supply Chain Management}

In recent years, several definitions of service supply chain have been provided. For example, Ellram's definition of service supply chain involves the management of information, processes, competencies, service functions and funds across the entire chain (from the initial supplier to the final customer) (Ellram et al., 2004). Baltacioglu, Ada, Kaplan, Yurt \& Kaplan (2007) defines the service supply chain as a network of suppliers, service providers, customers, and other support units, which represents the exchange of resources needed for service provision, conversion of these resources into primary and support services, and delivery of services to customers. Lately, definition of service supply chain has been extended to include Service Only Supply Chains (SOSCs) and Product Service Supply Chains (PSSCs).

SOSCs are fully concentrated on service provision and do not deal with any physical product (Wang, Wallace, Shen \& Choi, 2015). Real world examples of SOSCs can be easily found in Internet service, mobile service, finance, telecommunications, and tourism industries (Liu, Bai, Liu \& Wei, 2017). Baltacioglu's definition of service supply chain actually refers to SOSCs. Unlike SOSCs, PSSCs deals with both service and physical product (Wang et al., 2015). Notable examples of PSSCs are restaurants, food distribution chains, logistics chains, and hotel supply chains (Sampson \& Spring, 2012; Wang et al., 2015; Liu et al., 2017). Ellram's definition of service supply chain refers to PSSCs. In both modes of service supply chain however, service provision is realized by integration of service processes and capacities.

Many researchers have underscored the differences of service supply chains from manufacturing supply chains (Sengupta, Heiser \& Cook, 2006; Zhou, Park \& Yi, 2009), but there are also similarities between these two, which have inspired many works in this line of research (Liu et al., 2017). For example, Lin, Choy, Ho, Chung and Lam (2015) have taken inspiration from the supply chain framework of Lambert and Cooper (2000) to develop a service supply chain conceptual framework consisting of process management, component management, and network configuration. In this framework, process management refers to customer relationship management, demand management, supplier relationship management, financial management, risk management, information management, service provision management, and capacity and resource management. Liu et al. (2017) have also taken inspiration from manufacturing supply chain to develop a conceptual model for the effect of control power on the performance of service supply chain.

\subsection{Sustainable Supply Chain Management}

In 1987, the Brundtland report introduced the concept of sustainable development as "a development that meets the needs of the present without compromising the ability of future generations to meet their own needs" (WCED, 1987). Later, the concept of sustainability was extended to many fields including the supply chain management. There are many definitions of sustainable supply chain management (Touboulic \& Walker, 2015). For example, Carter and Rogers (2008) define sustainable supply chain management as "the strategic, transparent integration and achievement of an organization's social, environmental, and economic goals in the systemic coordination of key inter-organizational business processes for improving the long-term economic performance of the individual company and its supply chains". Lately, there has been a growing interest in Triple Bottom Line (TBL) approach toward sustainable supply chain management (Touboulic \& Walker, 2015). First introduced in 1990 (Willard, 2002), TBL concerns the company's value creation with social and environmental values taken into consideration 
(Elkington, 2004). The environmental dimension includes a series of activities, programs and mechanisms that encourage taking responsibility toward the environment and development and popularization of environmentallyfriendly technologies (Klassen, 2001). The social dimension involves both organizational and individual aspects, and while being founded upon material platform, it has an immaterial structure (Lehtonen, 2004). Unlike social and environmental dimensions, economic dimension is inherently quantitative and is focused on the resource utilization efficiency and return on capital (Rumelt, 1974).

In this study, sustainability of hospital supply chain refers to sustainability as defined by TBL concept with economic, social and environmental dimensions included.

\subsection{Sustainable Supply Chain Management from TBL Perspective}

\begin{tabular}{|c|c|c|c|c|}
\hline Authors & Year & Research Field & Type & Main Conclusion \\
\hline Securing \& Muller & 2008 & $\begin{array}{l}\text { Manufacture and } \\
\text { Service industry }\end{array}$ & Qualitative & $\begin{array}{l}\text { They discussed sustainability barriers in the service } \\
\text { sector based on external factors and provided a } \\
\text { conceptual framework of supplier risk. }\end{array}$ \\
\hline Samuel, et al. & 2010 & Service industry & Quantitative & $\begin{array}{l}\text { The purpose of this paper is to analyse health } \\
\text { service supply chain systems. System dynamics } \\
\text { models for a typical service-oriented supply chain } \\
\text { such as healthcare processes are developed, } \\
\text { wherein three service stages are presented } \\
\text { Sequentially. }\end{array}$ \\
\hline $\begin{array}{l}\text { Tseng, Lim, Wong, } \\
\text { Chen \& Zhan }\end{array}$ & 2016 & Service industry & $\begin{array}{l}\text { Quantitative } \\
\text { and Qualitative }\end{array}$ & $\begin{array}{l}\text { This paper developed a hierarchical network for } \\
\text { sustainable service supply chain management in a } \\
\text { closed-loop hierarchical structure. }\end{array}$ \\
\hline Hussain, et al. & 2015 & Service industry & Quantitative & $\begin{array}{l}\text { They develop a framework for evaluation of } \\
\text { sustainable supply chain performance in the service } \\
\text { sector includes four dimensions of customer } \\
\text { management, environmental management, social } \\
\text { accountability and risk management, safety and } \\
\text { health. then confirmed the model by confirmatory } \\
\text { factor analysis. }\end{array}$ \\
\hline $\begin{array}{l}\text { Hsu, Kuo, Chen } \\
\& \mathrm{Hu}\end{array}$ & 2013 & Service industry & $\begin{array}{l}\text { Quantitative } \\
\text { and Qualitative }\end{array}$ & $\begin{array}{l}\text { They conducted an empirical model to study the } \\
\text { impact of pressures, strategies, uncertainty, internal } \\
\text { management and external management on } \\
\text { sustainable supply chain practices in service } \\
\text { industry of Taiwan and Vietnam. Proved that these } \\
\text { five factors have a strong impact on the supply } \\
\text { chain in the service sector. }\end{array}$ \\
\hline $\begin{array}{l}\text { Ageron, } \\
\text { Gunasekaran \& } \\
\text { Spalanzani }\end{array}$ & 2012 & $\begin{array}{l}\text { Manufacture and } \\
\text { Service industry }\end{array}$ & Qualitative & $\begin{array}{l}\text { They provided a framework for a sustainable } \\
\text { supply chain and confirmed it. }\end{array}$ \\
\hline Hasan & 2013 & Service industry & Quantitative & $\begin{array}{l}\text { He examined the relationship between sustainable } \\
\text { supply chain and environmental / operational } \\
\text { performance. After presenting a framework, he } \\
\text { showed that the sustainable supply chain has an } \\
\text { important impact on environmental / operational } \\
\text { performance. }\end{array}$ \\
\hline Brandenburg et al. & 2015 & $\begin{array}{l}\text { Manufacture and } \\
\text { Service industry }\end{array}$ & $\begin{array}{l}\text { Quantitative } \\
\text { and Qualitative }\end{array}$ & $\begin{array}{l}\text { He focused on the concepts of pressures, risk, } \\
\text { supply and motivation management in the } \\
\text { sustainable supply chain model }\end{array}$ \\
\hline Liu et al. & 2017 & Service industry & Qualitative & $\begin{array}{l}\text { They provided a framework for assessing the } \\
\text { sustainable supply chain performance of the } \\
\text { service sector }\end{array}$ \\
\hline
\end{tabular}

Table 1. Sustainable supply chain management based on TBL 
Sustainable service supply chain management (SSSCM) is a new and under-researched branch of SCM literature. Table 1 shows the list of Some articles focused on SSSCM with TBL approach that are published from 2008 to 2017.

In an empirical research, Hussain et al. (2015) discussed how companies can stay productive and profitable, but also maintain sustainability. Using the confirmatory factor analysis, they assessed the UAE's service supply chains such as restaurants, airlines and hotels and produced a framework for sustainability measurement based on TBL criteria. They argued that service supply chain sustainability is a combination of four dimensions: environment management, social responsibility, health-safety-risk management, and customer management. Seuring and Müller (2008) have analyzed the external factors that pose a challenge to supply chain sustainability, and have argued that these factors generally fall in three categories of high costs, coordination difficulty and complexity, and lack of communication between groups. Ultimately, they provided a conceptual framework for improving supply chain performance and reducing risk. In the SSSCM framework provided by Liu et al. (2017), service integrators are considered as mediators between customer and service providers, and there is a high degree of interaction and coordination between service providers, service integrators, and customers, forming a ternary relationship. In addition, government and NGOs also have an impact on supply chain relationships. The mentioned ternary relationship is also subject to TBL conditions of sustainability. In this framework, service providers and integrators are considered as designers of strategy layers for sustainable management of service supply chain.

To study the notion of environmental sustainability of hospitals, Mcgain and Naylor (2014) have reviewed 76 studies published between 1990 and 2013. According to this study, the major lines of research on environmental sustainability of hospitals are: hospital design, energy consumption, procedures, travel, psychology and behavior.

\subsection{Fuzzy Cognitive Map (FCM)}

In 1976, Axelrod introduced the cognitive map as a method for modeling complex systems and identifying their causal relationships (Axelrod, 1976). Kosko (1986) modified the Axelrod's cognitive map to develop fuzzy cognitive map, (FCM), which he described as a fuzzy directional diagram where feedback is allowed (Kosko, 1988). Like the traditional cognitive maps, FCM consists of a number of nodes that represent variable concepts. A fuzzy cognitive map with $n$ concepts is represented by an $n \times n$ matrix. Generally, the causality relationship between two concepts is described by the nonlinear function e(ci, cj) representing the extent of influence of ci on cj. Schneider, Shnaider, Kandel and Chew (1998) developed a method for automatic generation of fuzzy cognitive map. Rodriguez-Repiso (2007) extended the Schneider's model to developed an advanced FCM based on four matrices: i) the initial matrix of success, ii) the fuzzified matrix of success, iii) the strength of relationship matrix of success, and iv) the final matrix of success.

\subsection{Intuitionistic Fuzzy}

Intuitionistic fuzzy set (IFS) is one of the generalizations of fuzzy sets theory (Zadeh, 1965). Out of several higherorder fuzzy sets, IFS, first introduced by Atanassov (1983), have been found to be more compatible to deal with vagueness. The conception of IFS can be viewed as an appropriate/alternative approach in cases where available information is not sufficient to define the impreciseness by the conventional fuzzy set. Fuzzy sets only consider the degree of acceptance, but IFS is characterized by a membership function and a non-membership function so that the sum of both values is less than one (Atanassov, 1986). Presently, IFSs are being studied and used in different fields of science. Among the research works on IFS we can mention Atanassov (1986, 1998, 1999, 2000), Atanassov and Gargov (1989), Szmidt and Kacprzyk (2000), Ban (2006), Deschrijver and Kerre (2002).

Definition 1 - Assume reference set $X=\left\{x_{1}, x_{2}, x_{3}, \ldots\right\}$. In this case, set $A$ which is a subset of $\mathrm{X}$ is an intuitionistic fuzzy set defined as below:

$$
A=\left\{\prec x, u_{A}(x), v_{A}(x) \succ \forall x \in X\right\}
$$

In the above definition, $u_{A}(x), v_{A}(x)$ are degree of membership and non-membership respectively, which are defined as $u_{A}(x): x \rightarrow[0,1], v_{A}(x): x \rightarrow[0,1]$ and satisfy $0 \leq u_{i j}(x)+v_{i j}(x) \leq 1$. In addition, for each $x \in X$, intuitionistic index $\pi_{x}$ is defined as $\pi_{x}=1-u_{x}-v_{x}$ (Atanassov, 1986).

Definition 2 - $\left(u_{i j}(x), v_{j j}(x), \pi_{i j}(x)\right)$ is an intuitionistic fuzzy number that satisfies the following conditions: 


$$
u_{i j}(x) \in[0,1], v_{i j}(x) \in[0,1], \pi_{i j}(x) \in[0,1], 0 \leq u_{i j}(x)+v_{i j}(x) \leq 1, \pi_{i j}(x)=1-u_{i j}(x)-v_{i j}(x)
$$

It must be noted that although intuitionistic fuzzy number is similar (in appearance) to triangular fuzzy number $(a, b, c)$, it is quite different. Triangular fuzzy number is a convex normal fuzzy set with a membership function in which $(a \prec b \prec c$ ); while an intuitionistic fuzzy number is a point in three-dimensional space constructed by axes $u_{i j}(x), v_{i j}(x), \pi_{j j}(x)$ (Szmidt \& Kacprzyk, 2000). Atanassov and Gargov (1998) have described intuitionistic fuzzy number $(0.50,0.20,0.30)$ as a scenario where votes in favor of adoption are 0.5 , votes against it are 0.2 and abstained votes are 0.30 .

In this context the following relationship holds true:

$$
\mu_{i j}^{\beta}(x)+v_{i j}^{\beta}(x) \leq 1,0 \leq \mu_{i j}^{\alpha}(x) \leq u_{i j}^{\beta}(x) \leq 1,0 \leq v_{i j}^{\alpha}(x) \leq v_{i j}^{\beta}(x) \leq 1
$$

These numbers are better suited to deal with uncertainty and provide a more logical mathematical framework to deal with inexact facts and incomplete information (Zhang, Jiang, Jia \& Luo, 2010). Some of the operators and relationships between these numbers are provided in the following. For simplicity's sake, these numbers are expressed as $\left[\mu_{i j}(x), v_{i j}(x), \pi_{i j}(x)\right]$ where $\mu_{i j}(x), v_{i j}(x)$ and $\pi_{i j}(x)$ are numbers in the range $[0,1]$.

Definition 3 - Assume intuitionistic fuzzy numbers $A=\left\{\left\langle x, \mu_{A}(x), v_{A}(x) \mid x \in X\right\rangle\right\}$ and $A_{1}=\left\{\left\langle x, \mu_{A 1}(x), v_{A 1}(x)\right|\right.$ $x \in X\rangle\}$ and $A_{2}=\left\{\left\langle x, \mu_{A 2}(x), v_{A 2}(x) \mid x \in X\right\rangle\right\}$ and the real number $n$. According to Xu and Cai (2012) the following relationships are defined:

$$
\begin{gathered}
\bar{A}=\left\{\left\langle x, v_{A}(x), \mu_{A}(x) \mid x \in X\right\rangle\right\} \\
A_{1} \cap A_{2}=\left\{\left\langle x, \min \left\{\mu_{A_{1}}(x), \mu_{A_{2}}(x)\right\}, \max \left\{v_{A_{1}}(x), v_{A_{2}}(x)\right\} \mid x \in X\right\rangle\right\} \\
A_{1} \cup A_{2}=\left\{\left\langle x, \max \left\{\mu_{A_{1}}(x), \mu_{A_{2}}(x)\right\}, \min \left\{v_{A_{1}}(x), v_{A_{2}}(x)\right\} \mid x \in X\right\rangle\right\} \\
A_{1}+A_{2}=\left\{\left\langle x, \mu_{A_{1}}(x)+\mu_{A_{2}}(x)-\mu_{A_{1}}(x) \cdot \mu_{A_{2}}(x), v_{A_{1}}(x) \cdot v_{A_{2}}(x) \mid x \in X\right\rangle\right\} \\
A_{1} \cdot A_{2}=\left\{\left\langle x, \mu_{A_{1}}(x) \cdot \mu_{A_{2}}(x), v_{A_{1}}(x)+v_{A_{2}}(x)-v_{A_{1}}(x) \cdot v_{A_{2}}(x) \mid x \in X\right\rangle\right\} \\
n A=\left\{\left\langle x, 1-\left(1-\mu_{A}(x)\right)^{n},\left(v_{A}(x)\right)^{n} \mid x \in X\right\rangle\right\} \\
A^{n}=\left\{\left\langle x,\left(\mu_{A}(x)\right)^{n}, 1-\left(1-v_{A}(x)\right)^{n} \mid x \in X\right\rangle\right\}
\end{gathered}
$$

Where $n$ is a Positive integer

\section{Method}

The purpose of this study was to identify the concepts influencing the sustainability of hospital supply chain for provide of framework of hospital sustainable supply chain and provide a causal model for sustainable supply chain of hospital service. There is extensive literature dedicated to sustainable supply chain management in manufacturing industry, but service supply chains have unique features that separate them from manufacturing industry, and the existing literature on the sustainability of these supply chains is still underdeveloped. In this study, 68 concepts that influence the sustainability of a hospital service supply chain were identified by in-depth interviewing of 18 experts in hospitals of Kerman, Iran. snowball sampling method was used for interviewing experts. In order to ensure the validity of the causal model designed in this research, the experts announced their corrective comments on the process and the results or confirmed them. Causal model was constructed with the intuitionistic fuzzy cognitive map (IFCM) method, which is an intuitionistic fuzzy extension of the model developed by Rogriguez-Repiso, Setchi and Salmeron (2007). In view of research objectives, this study was carried out in two phases. 


\subsection{Phase I: Development of Framework of Hospital Sustainable Supply Chain}

Considering the deficiency of subject literature, the concepts were identified by in-depth interviewing of healthcare experts in multiple stages. Given the large number of concepts and the resulting difficulties in development of framework, Delphi method was used to reorganize the initial concepts into 15 concepts.

\subsection{Phase II: Development of Causal Model of Sustainable Hospital Supply Chain Management with IFCM Method}

IFCM method consists of following steps.

Step 1 - Constructing the intuitionistic fuzzy matrix of success:

This is a $[n \times m]$ matrix where $\mathrm{n}$ is the number of sustainable hospital supply chain management concepts $\left(A_{i}\right)$ and $\mathrm{m}$ represents the number of hospital experts who provide the data $\left(E_{k}\right)$.

\begin{tabular}{|c|c|c|c|c|}
\hline \multicolumn{1}{r|}{ Experts } & $\boldsymbol{E}_{1}$ & $\boldsymbol{E}_{2}$ & $\ldots$ & $\boldsymbol{E}_{n}$ \\
\cline { 1 - 3 } Concepts & $\widetilde{r}_{11}$ & $\widetilde{r}_{12}$ & $\ldots$ & $\widetilde{\boldsymbol{r}}_{1 m}$ \\
\hline$A_{1}$ & $\widetilde{r}_{12}$ & $\widetilde{r}_{22}$ & $\ldots$ & $\widetilde{\boldsymbol{r}}_{2 m}$ \\
\hline$A_{2}$ & $\ldots$ & $\ldots$ & & $\ldots$ \\
\hline$\ldots$ & $\widetilde{r}_{n 1}$ & $\widetilde{r}_{n 2}$ & $\ldots$ & $\widetilde{r}_{n m}$ \\
\hline$A_{n}$ &
\end{tabular}

Table 2. Intuitionistic fuzzy matrix of success

In this matrix, $\widetilde{r}=\left[\mu_{i j}(x), v_{j j}(x), \pi_{i j}(x)\right]$ represents the intuitionistic fuzzy degree of importance given by expert $j$ to concept $i$ of the sustainable hospital supply chain management.

Step 2 - Constructing the strength of relationship matrix of success:

This is a $[n \times n]$ matrix where each element represents the relationship of factor $i$ with factor $j . S_{i j}$ can take values in the range $[-1,1]$. Each critical success factor is represented by the numerical vector $S_{i}$, which consist of $n$ elements, one for each concept in the map. There are three possible scenarios for relationship between concepts $i$ and $j$ :

- A direct relationship represented by $S_{i j}>0$

- An inverse relationship represented by $S_{i j}<0$

- No relationship represented by $S_{i j}=0$

Assuming $\widetilde{V}_{i}$ as the intuitionistic fuzzy vector of $m$ elements related to concept $i$, the similarity of relationships between vectors $\widetilde{V}_{i}$ and $\widetilde{V}_{j}$ will be:

This gives the strength of relationship between concepts $i$ and $j$ as the similarity of these two vectors, represented by $S_{i j}$. The similarity of two vectors is measured by their distance, as defined in the intuitionistic fuzzy logic. In this study, this distance was considered to be the normalized Euclidean distance given by the following formula:

As a result, the closeness or similarity of two factors $\left(S_{i j}\right)$ is given by:

$S=1$ signifies perfect similarity and $S=0$ means no similarity.

Step 3 - Constructing the final matrix of success:

The matrix obtained from the previous step contains some data that might be misleading. Simply put, some of the concepts of the matrix may be unrelated to each other and have no causal relationship. Thus, to construct the final matrix of success, expert inputs are again used to separate those intuitionistic fuzzy elements that represent causal relationships between concepts.

Step 4 - Graphical representation of intuitionistic fuzzy cognitive map: 
In this step, the results are plotted as an intuitionistic cognitive map of critical success factors. In this graphical representation, causal relationship between two concepts is represented by an arrow, which has a weight representing the strength of this direct or inverse relationship.

\section{Results}

In this section, the results are presented in two phases in accordance with the phases described in the previous section.

\subsection{Phase I: Development of Framework of Hospital Sustainable Supply Chain}

As previously mentioned, because of the deficiency of the literature in regard to this particular subject, the concepts were mostly identified by in-depth interviewing of healthcare experts. Hospitals of Kerman were considered as the domain of study. Initial list of interviewees was composed by theoretical sampling. This initial list was then completed by snowball sampling. The final list consisted of 18 people, including 6 environmental experts, 3 hospital department heads, 6 resource and development deputies, and 3 administrative deputies, all with at least 8 years of experience in their line of work and familiarity with the subject of sustainability. From in-depth interviews, a total of 68 concepts associated with the sustainability of hospital supply chain were extracted. Considering the large number of extracted concepts (68 concepts) and the resulting difficulties in development of causal model, Delphi method was used to reorganize the outputs into 15 major concepts. Delphi procedure was carried out with the help of 6 of 18 experts who participated in the previous stage. The final list of major concepts associated with the sustainability of hospital supply chain is presented in Table 3. It should also be noted that the concepts: demand management, resource and capacity management, customer relationship management, supplier relationship management, service provision management, information management, and financial performance management were derived from the service supply chain management frameworks proposed by Lambert \& Cooper (2000) and Lin et al. (2010).

\begin{tabular}{|c|c|}
\hline Main Concepts & Concepts \\
\hline \multirow{3}{*}{ Attention to the environment $(\mathrm{c} 1)$} & Patient attention to environmental protection \\
\hline & The pressure of suppliers to provide environmentally friendly services \\
\hline & The patient's request for an environmentally friendly treatment \\
\hline \multirow{4}{*}{ Contaminations (c2) } & Waste and waste volume \\
\hline & Percentage of toxic waste \\
\hline & Critical waste \\
\hline & Release of chemical gases \\
\hline \multirow{3}{*}{ Energy consumption (c3) } & Water consumption \\
\hline & Gas consumption \\
\hline & Power consumption \\
\hline \multirow{4}{*}{ Legal requirements (c4) } & Government laws on energy efficiency \\
\hline & Government regulations on environmental waste \\
\hline & Government regulations on waste reduction \\
\hline & National and regional environmental laws \\
\hline \multirow{4}{*}{ Social responsibility (c5) } & The volume of social investment \\
\hline & Education in the community about health \\
\hline & Complaints handling \\
\hline & Creation of Job Opportunities \\
\hline \multirow[t]{3}{*}{ Personnel (c6) } & Employee satisfaction \\
\hline & Equal Opportunities for Employees (Upgrade and Reward) \\
\hline & Employee development and motivation \\
\hline
\end{tabular}




\begin{tabular}{|c|c|}
\hline & Work safety and employee health \\
\hline & Work environment health \\
\hline & Worker's work life Quality \\
\hline 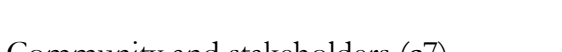 & Stakeholder Satisfaction \\
\hline 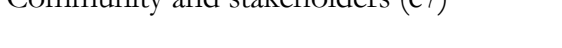 & Interacting with stakeholders \\
\hline & Stakeholder Cooperation \\
\hline & Patient privacy \\
\hline Business ethics (c8) & Reduce corruption and bribes \\
\hline & Employee privacy \\
\hline Demand manocement $(r 0)$ & patient needs Prediction \\
\hline Demand management (cy) & The accuracy of prediction techniques \\
\hline & Service capacity \\
\hline & Consuming services \\
\hline Resource and capacity management (c10) & Capital \\
\hline & Staff training \\
\hline & Management Ability of facilities, manpower and capital \\
\hline & Patient loyalty \\
\hline & Patient satisfaction \\
\hline Customer relation management (c11) & Patient value \\
\hline & Patient profitability \\
\hline & Attracting patients \\
\hline & Customer relationship management \\
\hline & Level and degree of information exchange \\
\hline & The level of cooperation has led to continuous improvement \\
\hline & Speed of service provision \\
\hline Supplier relationship management (c12) & Quality level \\
\hline & Flexibility in workload and specifications \\
\hline & Efficiency in services delivery \\
\hline & Pricing unlike the market \\
\hline & Continuous communication with supply \\
\hline & Service Value \\
\hline & The speed of service delivery \\
\hline & Keeping promises to Customer \\
\hline Sol & Services Provision cost \\
\hline service management (c15) & Staff absenteeism \\
\hline & The proportion of working hours to the planned \\
\hline & Profit marigin \\
\hline & Physical beauty of sections \\
\hline & Adhere to standards and rules \\
\hline Ioformotion mon 12$)$ & The amount of information sharing \\
\hline Information management (c13) & Accuracy of information \\
\hline & Keep up to date of information \\
\hline
\end{tabular}




\begin{tabular}{|l|l|}
\hline \multicolumn{1}{|c|}{ Main Concepts } & \multicolumn{1}{c|}{ Concepts } \\
\hline \multirow{4}{*}{ Financial management (c14) } & Cash flow rate \\
\cline { 2 - 2 } & Investment return rate \\
\cline { 2 - 2 } & Payment flows between sectors \\
\cline { 2 - 2 } & Reduce costs due to the quality of service delivery \\
\cline { 2 - 2 } & Maintenance cost \\
\hline
\end{tabular}

Table 3. Framework of hospital sustainable supply chain

\subsection{Phase II: Development of Causal Model of Sustainable Hospital Supply Chain Management with IFCM Method}

After identification of major concepts in phase 1, IFCM method was used to develop the causal model of sustainable hospital supply chain management in 4 steps:

Step 1 - constructing the intuitionistic fuzzy matrix of success:

There were 15 final concepts and 18 experts available for analysis, so an $18 \times 15$ matrix was created. Experts were asked to describe the importance of each concept for the sustainability of hospital supply chain management by one of five linguistic terms given in Table 4. To simplify the analysis, these terms were also assigned with codes 1 to 5 , representing the lack of impact, weak impact, moderate impact, strong impact, and very strong impact, respectively.

\begin{tabular}{|l|c|}
\hline \multicolumn{1}{|c|}{ Linguistic terms } & IFNs \\
\hline No Influence & $(0.1,0.9)$ \\
\hline Very Low Influence & $(0.35,0.6)$ \\
\hline Low Influence & $(0.5,0.45)$ \\
\hline High Influence & $(0.75,0.2)$ \\
\hline Very High Influence & $(0.9,0.1)$ \\
\hline
\end{tabular}

Table 4. Intuitionistic fuzzy linguistic terms

The intuitionistic fuzzy degree of importance of every concept was obtained by the method described in section 3.2. As mentioned, this parameter represents the importance of concept i for sustainability of hospital supply chain management in view of expert $j$. The results of this step are presented in Table 5.

\begin{tabular}{|c|c|c|c|c|c|c|c|c|c|}
\hline & 1 & 2 & 3 & 4 & 5 & 6 & 7 & 8 & 9 \\
\hline C1 & $(0.36,0.6)$ & $(0.75,0.2)$ & $(0.5,0.45)$ & $(0.36,0.6)$ & $(0.75,0.2)$ & $(0.75,0.2)$ & $(0.5,0.45)$ & $(0.1,0.9)$ & $(0.5,0.45)$ \\
\hline C2 & $(0.5,0.45)$ & $(0.75,0.2)$ & $(0.75,0.2)$ & $(0.9,0.1)$ & $(0.75,0.2)$ & $(0.9,0.1)$ & $(0.5,0.45)$ & $(0.5,0.45)$ & $(0.5,0.45)$ \\
\hline C3 & $(0.75,0.2)$ & $(0.75,0.2)$ & $(0.75,0.2)$ & $(0.9,0.1)$ & $(0.75,0.2)$ & $(0.9,0.1)$ & $(0.5,0.45)$ & $(0.5,0.45)$ & $(0.75,0.2)$ \\
\hline$\ldots$ & $\ldots$ & $\ldots$ & $\ldots$ & $\ldots$ & $\ldots$ & $\ldots$ & $\ldots$ & $\ldots$ & $\ldots$ \\
\hline C13 & $(0.75,0.2)$ & $(0.5,0.45)$ & $(0.9,0.1)$ & $(0.5,0.45)$ & $(0.36,0.6)$ & $(0.1,0.9)$ & $(0.36,0.6)$ & $(0.5,0.45)$ & $(0.5,0.45)$ \\
\hline C14 & $(0.75,0.2)$ & $(0.5,0.45)$ & $(0.75,0.2)$ & $(0.5,0.45)$ & $(0.36,0.6)$ & $(0.5,0.45)$ & $(0.36,0.6)$ & $(0.36,0.6)$ & $(0.75,0.2)$ \\
\hline C15 & $(0.9,0.1)$ & $(0.75,0.2)$ & $(0.75,0.2)$ & $(0.5,0.45)$ & $(0.36,0.6)$ & $(0.5,0.45)$ & $(0.36,0.6)$ & $(0.36,0.6)$ & $(0.5,0.45)$ \\
\hline
\end{tabular}




\begin{tabular}{|c|c|c|c|c|c|c|c|c|c|}
\hline & 10 & 11 & 12 & 13 & 14 & 15 & 16 & 17 & 18 \\
\hline C1 & $(0.36,0.6)$ & $(0.1,0.9)$ & $(0.5,0.45)$ & $(0.36,0.6)$ & $(0.5,0.45)$ & $(0.5,0.45)$ & $(0.5,0.45)$ & $(0.1,0.9)$ & $(0.75,0.2)$ \\
\hline C2 & $(0.5,0.45)$ & $(0.5,0.45)$ & $(0.75,0.2)$ & $(0.5,0.45)$ & $(0.9,0.1)$ & $(0.5,0.45)$ & $(0.9,0.1)$ & $(0.75,0.2)$ & $(0.9,0.1)$ \\
\hline C3 & $(0.5,0.45)$ & $(0.75,0.2)$ & $(0.9,0.1)$ & $(0.9,0.1)$ & $(0.9,0.1)$ & $(0.5,0.45)$ & $(0.9,0.1)$ & $(0.75,0.2)$ & $(0.9,0.1)$ \\
\hline$\ldots$ & $\ldots$ & $\ldots$ & $\ldots$ & $\ldots$ & $\ldots$ & $\ldots$ & $\ldots$ & $\ldots$ & $\ldots$ \\
\hline C13 & $(0.36,0.6)$ & $(0.5,0.45)$ & $(0.5,0.45)$ & $(0.36,0.6)$ & $(0.5,0.45)$ & $(0.5,0.45)$ & $(0.5,0.45)$ & $(0.5,0.45)$ & $(0.9,0.1)$ \\
\hline C14 & $(0.36,0.6)$ & $(0.75,0.2)$ & $(0.5,0.45)$ & $(0.75,0.2)$ & $(0.9,0.1)$ & $(0.75,0.2)$ & $(0.9,0.1)$ & $(0.75,0.2)$ & $(0.9,0.1)$ \\
\hline C15 & $(0.36,0.6)$ & $(0.5,0.45)$ & $(0.75,0.2)$ & $(0.9,0.1)$ & $(0.9,0.1)$ & $(0.75,0.2)$ & $(0.75,0.2)$ & $(0.75,0.2)$ & $(0.9,0.1)$ \\
\hline
\end{tabular}

Table 5. The intuitionistic fuzzy matrix of success

Step 2 - constructing the strength of relationship matrix of success:

This matrix, which shows the closeness of two concepts, was obtained using Equation (10) and (11). The resulting strength of relationship matrix is given in Table 6 .

\begin{tabular}{|c|c|c|c|c|c|c|c|c|c|c|c|c|c|c|c|}
\hline & C1 & C2 & C3 & C4 & C5 & C6 & C7 & C8 & C9 & C10 & C11 & C12 & C13 & C14 & C15 \\
\hline C1 & & 0.54 & 0.43 & 0.57 & 0.63 & 0.50 & 0.51 & 0.61 & 0.62 & 0.40 & 0.62 & 0.59 & 0.5 & 0.47 & 0.49 \\
\hline C2 & 0.54 & & 0.78 & 0.71 & 0.67 & 0.74 & 0.70 & 0.72 & 0.57 & 0.68 & 0.65 & 0.70 & 0.5 & 0.65 & 0.66 \\
\hline C3 & 0.43 & 0.78 & & 0.70 & 0.65 & 0.70 & 0.71 & 0.65 & 0.47 & 0.72 & 0.60 & 0.63 & 0.4 & 0.68 & 0.68 \\
\hline C4 & 0.57 & 0.71 & 0.70 & & 0.81 & 0.75 & 0.75 & 0.76 & 0.62 & 0.63 & 0.69 & 0.76 & 0.6 & 0.74 & 0.77 \\
\hline C5 & 0.63 & 0.67 & 0.65 & 0.81 & & 0.71 & 0.78 & 0.76 & 0.72 & 0.60 & 0.76 & 0.76 & 0.7 & 0.72 & 0.73 \\
\hline C6 & 0.50 & 0.74 & 0.70 & 0.75 & 0.71 & & 0.80 & 0.76 & 0.59 & 0.65 & 0.71 & 0.77 & 0.6 & 0.73 & 0.74 \\
\hline C7 & 0.51 & 0.70 & 0.71 & 0.75 & 0.78 & 0.80 & & 0.76 & 0.63 & 0.62 & 0.71 & 0.74 & 0.6 & 0.74 & 0.75 \\
\hline C8 & 0.61 & 0.72 & 0.65 & 0.76 & 0.76 & 0.76 & 0.76 & & 0.68 & 0.65 & 0.77 & 0.85 & 0.7 & 0.75 & 0.74 \\
\hline C9 & 0.62 & 0.57 & 0.47 & 0.62 & 0.72 & 0.59 & 0.63 & 0.68 & & 0.47 & 0.75 & 0.68 & 0.7 & 0.62 & 0.60 \\
\hline C10 & 0.40 & 0.68 & 0.72 & 0.63 & 0.60 & 0.65 & 0.62 & 0.65 & 0.47 & & 0.61 & 0.63 & 0.4 & 0.65 & 0.61 \\
\hline C11 & 0.62 & 0.65 & 0.60 & 0.69 & 0.76 & 0.71 & 0.71 & 0.77 & 0.75 & 0.61 & & 0.78 & 0.6 & 0.73 & 0.71 \\
\hline C12 & 0.59 & 0.70 & 0.63 & 0.76 & 0.76 & 0.77 & 0.74 & 0.85 & 0.68 & 0.63 & 0.78 & & 0.7 & 0.73 & 0.74 \\
\hline C13 & 0.54 & 0.54 & 0.49 & 0.65 & 0.71 & 0.63 & 0.68 & 0.72 & 0.74 & 0.48 & 0.69 & 0.71 & 0.74 & 0.6 & 0.64 \\
\hline C14 & 0.47 & 0.65 & 0.68 & 0.74 & 0.72 & 0.73 & 0.74 & 0.75 & 0.62 & 0.65 & 0.73 & 0.73 & 0.65 & 0.70 \\
\hline C15 & 0.49 & 0.66 & 0.68 & 0.77 & 0.73 & 0.74 & 0.75 & 0.74 & 0.60 & 0.61 & 0.71 & 0.74 & 0.64 & 0.8 & \\
\hline
\end{tabular}

Table 6. Strength of relationship matrix of success

Step 3 - constructing the final matrix of success:

As mentioned, the strength of relationship matrix may contain misleading data signifying false causal relationships between concepts. To avoid false results, all 18 experts were asked to reexamine this matrix and express their views on the derived inter-concept relationships. Accordingly, the false relations were removed and the final matrix was obtained (Table 7). 


\begin{tabular}{|c|c|c|c|c|c|c|c|c|c|c|c|c|c|c|c|}
\hline & c1 & c2 & c3 & c4 & c5 & c6 & c7 & c8 & c9 & c10 & c11 & c12 & c13 & c14 & c15 \\
\hline c1 & 0 & -0.54 & -0.4 & 0 & 0 & 0 & 0 & 0 & 0 & 0 & 0 & 0 & 0 & 0 & 0 \\
\hline c2 & 0 & 0 & 0 & 0 & 0 & 0 & -0.70 & 0 & 0 & 0 & 0 & 0 & 0 & 0 & 0 \\
\hline c3 & 0 & 0 & 0 & 0 & 0 & 0 & 0 & 0 & 0 & 0 & 0 & 0 & 0 & -0.68 & 0 \\
\hline c4 & 0 & -0.71 & 0 & 0 & 0 & 0 & 0 & 0 & 0 & 0 & 0 & 0 & 0 & 0 & 0 \\
\hline c5 & 0 & 0 & 0 & 0 & 0 & 0 & 0.78 & 0 & 0 & 0 & 0 & 0 & 0 & 0 & 0 \\
\hline c6 & 0 & 0 & 0 & 0 & 0.71 & 0 & 0 & 0.76 & 0 & 0 & 0 & 0 & 0 & 0 & 0 \\
\hline c7 & 0 & 0 & 0.71 & 0 & 0 & 0 & 0 & 0.76 & 0 & 0 & 0 & 0 & 0 & 0 & 0 \\
\hline c8 & 0 & 0 & 0 & 0 & 0 & 0 & 0 & 0 & 0 & 0 & 0 & 0 & 0 & 0.75 & 0.7 \\
\hline c9 & 0 & 0 & 0 & 0 & 0 & 0 & 0 & 0 & 0 & 0 & 0 & 0 & 0 & 0 & 0.6 \\
\hline c10 & 0 & 0 & 0 & 0 & 0 & 0 & 0 & 0 & 0 & 0 & 0.61 & 0.63 & 0 & 0 & 0.6 \\
\hline c11 & 0 & 0 & 0 & 0 & 0 & 0 & 0 & 0 & 0 & 0 & 0 & 0 & 0 & 0 & 0.7 \\
\hline c12 & 0 & 0 & 0 & 0 & 0 & 0 & 0 & 0 & 0 & 0 & 0 & 0 & 0 & 0 & 0.7 \\
\hline c13 & 0 & 0 & 0 & 0 & 0 & 0 & 0 & 0 & 0.74 & 0 & 0 & 0 & 0 & 0 & 0.6 \\
\hline c14 & 0 & 0 & 0 & 0 & 0 & 0 & 0 & 0 & 0 & 0.65 & 0 & 0 & 0 & 0 & 0.8 \\
\hline c15 & 0 & -0.66 & -0.6 & 0 & 0 & 0 & 0 & 0 & 0 & -0.61 & 0 & 0 & 0 & 0 & 0 \\
\hline
\end{tabular}

Table 7. The final matrix of success

Using this matrix, the causal model of sustainable hospital supply chain management was plotted as shown in Figure 1.

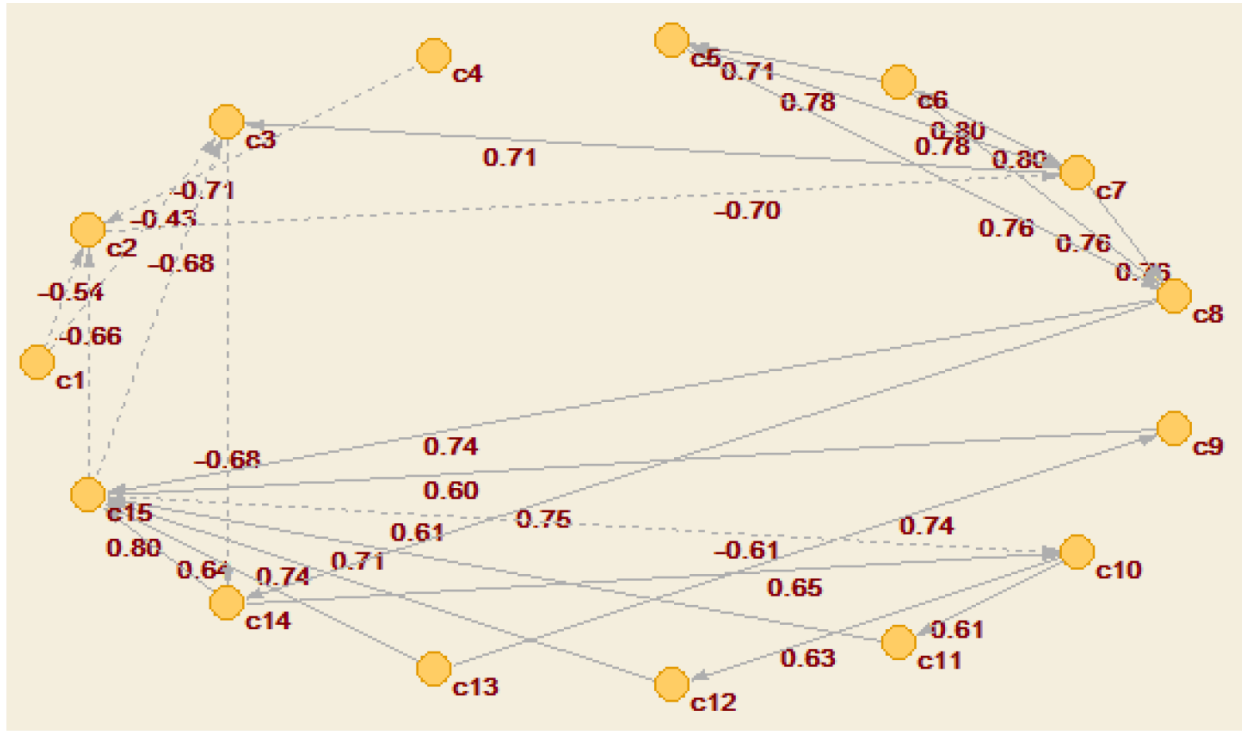

Figure 1. Causal Model of Sustainable Hospital Supply Chain Management

\section{Results and Discussion}

The purpose of this study was to provide a causal model for sustainable hospital supply chain management. For this purpose, first the major concepts associated with the sustainability of hospital supply chain were extracted. This task was carried out according to the notions implied in the supply chain framework proposed by Lin et al. (2015). In this framework, it is indicated service supply chain management is founded upon three processes, namely process management, component management and network configuration, which implies that the concepts must be extracted on the basis of these processes. Accordingly, the targeted concepts were extracted by in-depth interviewing of 18 healthcare experts with the processes considered as the basis of service supply chain 
management. The extracted concepts included all three dimensions of sustainability, namely, environmental impacts, social impacts, and economic efficiency. In the environmental dimension, concepts were organized into four major concepts of regulatory requirements, energy consumption, pollution, and environmental awareness. The concepts in the social dimension were organized into four major concepts of society, stakeholders, business ethics and employees. In the economic dimension, concepts were organized into seven major concepts related to supply chain processes. Most sustainable supply chain studies have provided a framework for chain supply of manufacturing industries. There are few quantitative studies on the supply chain of sustainable services. In the sustainable supply chain research, few studies have simultaneously addressed environmental, social and economic dimensions. Studies conducted by Hussain et al. (2015), Seuring and Muller (2008) and Liu et al. (2017) are considered as three classical research in the field of sustainable supply chain of services that have been addressed in the Literature Review. According to Hussein et al. (2015) the sustainability of supply chain of services can be a combination of four dimensions of environmental management, social accountability, customer management, and health, risk and security management. In this research, client management is only considered from the supply chain processes of services, and there is no discussion of the eight supply chain processes of services. Seuring and Muller (2008) developed only a supply chain management framework from a risk-taking perspective without providing an explanation of sustainability at the level of supply chain application; although, in the theoretical aspect, describing the supply chain management framework of services with aspects of the triple criteria is essential. The framework proposed by Liu et al. (2017) addresses the deficiencies identified in the aforementioned studies and outlines the framework for supply chain management with aspects of the triple criteria; nevertheless, the management of processes that is discussed in most supply chain studies, is not considered. All the frameworks presented in the field of supply chain of services are based on a common concept: the process management (customer relationship management, information management, event management, order management, service management, supplier relationship management, financial performance management, capacity management and demand management) is considered as the main concept in the supply chain of services.

After identification of concepts, the causal model was developed with intuitionistic fuzzy cognitive map (IFCM) method. For this purpose, the Rogriguez' fuzzy cognitive map method was combined with the principles of intuitionistic fuzzy set (IFS) logic, which is more effective in dealing with impreciseness and uncertainty. For further static analysis, the output was used to plot the map of causal model of sustainable hospital supply chain management, where centrality of nodes (concepts) can be a suitable measure for this analysis. Centrality of a node is a measure of how influencing the node is, which is quantified by its outdegree, or the sum of absolute values of its outbound links, and how strongly the node is influenced by other nodes, which is quantified by its indegree, or the sum of absolute values of its inbound links. Outdegree, indegree and centrality of each node are given in Table 8.

As shown in Table 8, the concepts "service management" (c15) and "regulatory requirements" (c5) have the highest and lowest degree of centrality, respectively. This indicates that regulatory requirements have a lowest sum of outdegree and indegree among concepts. For better clarity, the results of Table 7 are illustrated in four regions of the plot shown in Figure 2. For this illustration, all outdegrees and indegrees are scaled normalized to the interval $[0,1]$. 


\begin{tabular}{|c|r|r|r|r|r|}
\hline Concepts & Outdegree & Indegree & Centrality & \%Outdegree & \% Indegree \\
\hline c1 & 0.97 & 0.00 & 0.97 & 0.388 & 0 \\
\hline c2 & 0.70 & 1.91 & 2.61 & 0.28 & 0.394628 \\
\hline c3 & 0.68 & 1.82 & 2.50 & 0.272 & 0.376033 \\
\hline c4 & 0.71 & 0.00 & 0.71 & 0.284 & 0 \\
\hline c5 & 0.78 & 0.71 & 1.49 & 0.312 & 0.146694 \\
\hline c6 & 1.47 & 0.00 & 1.47 & 0.588 & 0 \\
\hline c7 & 1.47 & 1.48 & 2.95 & 0.588 & 0.305785 \\
\hline c8 & 1.49 & 1.52 & 3.01 & 0.596 & 0.31405 \\
\hline c9 & 0.60 & 0.74 & 1.34 & 0.24 & 0.152893 \\
\hline c10 & 2.50 & 1.26 & 3.76 & 0.998022 & 0.260331 \\
\hline c11 & 0.71 & 0.61 & 1.32 & 0.284 & 0.126033 \\
\hline c12 & 0.74 & 0.63 & 1.37 & 0.296 & 0.130165 \\
\hline c13 & 1.38 & 0.00 & 1.38 & 0.552 & 0 \\
\hline c14 & 1.45 & 2.08 & 3.53 & 0.58 & 0.4287 \\
\hline c15 & 1.95 & 4.84 & 6.79 & 0.78 & 1 \\
\hline
\end{tabular}

Table 8. Outdegree, indegree and centrality of each node

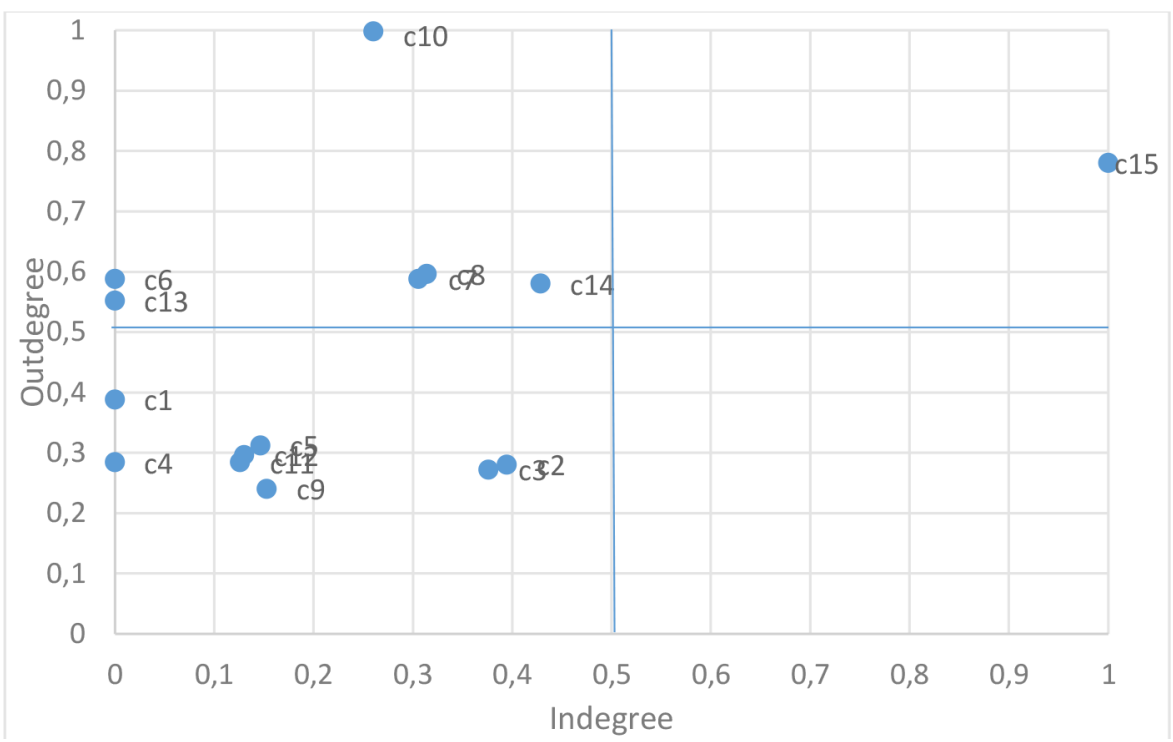

Figure 2. Grouping nodes in four regions

Region 1: this region includes the concepts with high outdegree and high indegree, namely c15. A concept that falls in this region needs to be carefully administered for a more sustainable hospital supply chain management to be reached.

Region 2: this region includes the concepts with a high outdegree but a low indegree, and includes c8, c6, c7, c13, c14 and c10. The significance of these concepts lies in their high potential to trigger change, which indicates the need for special attention.

Region 3: this region includes the concepts with a low outdegree and a high indegree. Any concept in this region will be difficult to manage as it will be influenced by many other concepts. In this study, none of the concepts fell in this region. 
Region 4: this region includes the concepts that have low outdegree as well as a low indegree. A low outdegree and indegree means that these concepts are highly isolated and have the most limited management implications. In this study, the concepts $\mathrm{c} 2, \mathrm{c3}, \mathrm{c4}, \mathrm{c} 8, \mathrm{c} 9, \mathrm{c} 11, \mathrm{c} 12$ and $\mathrm{c} 1$ fell in this region.

\section{Conclusion}

Sustainable service supply chain management is a subject of growing interest to researchers in the field of supply chain management. As mentioned in the previous sections, there is a gap in the exiting sustainable service supply chain management literature, in the sense that many of the existing frameworks neglect one or more aspects of this subject. For example, the framework proposed by Seuring and Müller (2008) deals with supply chain processes without considering the sustainability dimension and the framework proposed by Hussein et al. (2015) is extensively focused on customer management at the expense of other supply chain processes. To address this issue in the field of our interest, that is healthcare, we identified the concepts influencing sustainability of hospital supply chain management by interviewing the experts on the subject and then developed a causal model for sustainable hospital sustainable supply chain management. Contributions of this study include the identification of concepts affecting the sustainability of hospital supply chain, which is the first research on this particular subject; development of the causal model of these concepts with the intuitionistic fuzzy cognitive map (IFCM) method, a model that can provide greater insight into the issue of sustainability of hospital supply chain and can also be used in dynamic systems; and lastly initiation of a new avenue of quantitative research in the field of sustainable service supply chain management. Future researches can utilize this study as a template to extend the notion of sustainability to other service chains such as banks, hotels, and restaurants, or as a basis for further quantitative research into sustainable supply chain management at operational level. Further, healthcare officials, especially those involved with hospitals service management, can utilize the presented model to improve the supply chain management performance.

\section{Declaration of Conflicting Interests}

The authors declared no potential conflicts of interest with respect to the research, authorship, and/or publication of this article.

\section{Funding}

The authors received no financial support for the research, authorship, and/or publication of this article.

\section{References}

Ageron, B., Gunasekaran, A., \& Spalanzani, A. (2012). Sustainable supply management: An empirical study. Int. J. Prod. Econ, 140, 168-182. https://doi.org/10.1016/j.ijpe.2011.04.007

Ahi, P., \& Searcy, C. (2013). A comparative literature analysis of definitions for green and sustainable supply chain management. Journal of Cleaner Production, 52, 329-341. https://doi.org/10.1016/j.jclepro.2013.02.018

Ahi, P., \& Searcy, C. (2015). Assessing sustainability in the supply chain: A triple bottom line approach. Applied Mathematical Modelling, 39(10), 2882-2896. https://doi.org/10.1016/j.apm.2014.10.055

Angerhofer, B.J., \& Angelides, M.C. (2000). System Dynamics Modeling in Supply Chain Management: Research Review. Proceedings of Simulation Conference.

Atanassov, K., \& Gargov, G. (1998). Elements of intuitionistic fuzzy logic. Part I. Fuzzy Sets and Systems, 95(1), 39-52. https://doi.org/10.1016/S0165-0114(96)00326-0

Atanassov, K.T. (2000). Two theorems for intuitionistic fuzzy sets. Furay Sets and Systems, 110(2), 267-269. https://doi.org/10.1016/S0165-0114(99)00112-8

Atanassov, K. (1983). Intuitionistic Fuzzy Sets. VII ITKR Session. Sofia (Deposed in Centr. Sci.-Techn. Library of Bulg. Acad. of Sci. (1697/84) (in Bulgarian).

Atanassov, K. (1986). Intuitionistic Fuzzy Sets. Fuz:y Sets and Systems, 20, 87-96. https://doi.org/10.1016/S01650114(86)80034-3

Atanassov, K. (1999). Intuitionistic Fuz:y Sets: Theory and Applications. Springer. https://doi.org/10.1007/978-3-7908$1870-3$ 
Axelrod, R. (1976). Structure of Decision: The Cognitive Maps of Political Elites. Princeton, NJ: Princeton University Press.

Baltacioglu, T., Ada, E., Kaplan, M.D., Yurt, O., \& Kaplan, Y.C. (2007). A New Framework for Service Supply Chains. The Service Industries, 27(2), 105-124. https://doi.org/10.1080/02642060601122629

Ban, A.I. (2006). Nearest interval approximation of an intuitionistic fuzzy number. In Reusch, B. (Ed.), Computational Intelligence, Theory and Applications (229-240). Berlin: Springer.

Brandenburg, M., Govindan, K., Sarkis, J., \& Seuring, S. (2015). Quantitative models for sustainable supply chain management: Developments and directions. European Journal of Operational Research, 233(2), 299-312.

https://doi.org/10.1016/j.ejor.2013.09.032

Carter, C.R., \& Roger, D.S. (2008). A framework of sustainable supply chain management: moving toward new theory. International Journal of Physical Distribution \& Logistics Management, 38(5), 360-387. https://doi.org/10.1108/09600030810882816

Chang, Y., \& Harris, M. (2001). Supply chain modeling using simulation. International Journal of Simulation: Systems, Science \& Technology, 2(1), 24-30.

Cho, D.W., Lee, Y.H., Ahn, S.H., \& Hwang, M.K. (2012). A framework for measuring the performance of service supply chain management. Computers \& Industrial Engineering, 62, 801-818. https://doi.org/10.1016/j.cie.2011.11.014

Chung, J.W., \& Meltzer, D.O. (2009). Estimate of the carbon footprint of the US health care sector. Journal of the American Medical Association, 302(18), 1970-1972. https://doi.org/10.1001/jama.2009.1610

Cucek, L., Klemeš, J.J., \& Kravanja, Z., (2012). A review of footprint analysis tools for monitoring impacts on sustainability. J. Cleaner Prod., 34, 9-20. https://doi.org/10.1016/j.jclepro.2012.02.036

Deschrijver, G., \& Kerre, E.E. (2002). On the relationship between intuitionistic fuzzy sets and some other extensions of fuzzy set theory'. J Fuz:y Math, 10(3), 711-724.

Elkington, J. (2004). The Triple Bottom Line: does it all add up? London: Earthscan.

Ellram, L., Tate, W., \& Billington, C. (2004). Understanding and managing the services supply chain. Journal of Supply Chain Management, 40(4), 17-32. https://doi.org/10.1111/j.1745-493X.2004.tb00176.x

Gaussin, M., Hu, G., Abolghasem, S., Basu, S., Shankar, M.R., \& Bidanda, B. (2013). Assessing the environmental footprint of manufactured products: A survey of current literature. International Journal of Production Economics, 146(2), 515-523. https://doi.org/10.1016/j.ijpe.2011.12.002

Guillén, G. (2005). Multiobjective supply chain design under uncertainty. Chemical Engineering Science, 60, $1535-1553$. https://doi.org/10.1016/j.ces.2004.10.023

Gunasekaran, A., Patel, C., \& McGaughey, R.E. (2004). A framework for supply chain performance measurement. International Journal of Production Economics, 87(3), 333-347. https://doi.org/10.1016/j.ijpe.2003.08.003

Haksever, C., \& Render, B. (2013). Service Management: An Integrated Approach to Supply Chain Management and Operations. FT Press.

Hasan M. (2013). Sustainable supply chain management practices and operational performance. AmJ Ind Bus Manag, 3, 42-48. https://doi.org/10.4236/ajibm.2013.31006

Hsu, C.W., Kuo, T.C., Chen, S.H., \& Hu, A.H. (2013). Using DEMATEL to develop a carbon management model of supplier selection in green supply chain management. Journal of Cleaner Production, 56, 164-172.

https://doi.org/10.1016/j.jclepro.2011.09.012

Huang, G.Q., Lau, J.S.K., \& Mak, K.L. (2003). The impacts of sharing production information on supply chain dynamics: a review of the literature. International Journal of Production Research, 41(7), 1483-1517. https://doi.org/10.1080/0020754031000069625

Hult, G.T.M., Ketchen, D.J., \& Arrfelt, M. (2007). Strategic supply chain management: improving performance through a culture of competitiveness and knowledge development. Strategic Management Journal, 28(10), 1035.

https://doi.org/10.1002/smj.627 
Hussain, M., Khan, M., \& Al-Aomar, R.A. (2015). framework for supply chain sustainability in service industry with CFA. Renew. Sustain. Energy Rev, 55, 1301-1312. https://doi.org/10.1016/j.rser.2015.07.097

Iranian Statistics Center (2014). Labor Force Survey Results. Tehran: Iran Statistics Center.

Klassen, R.D. (2001). Plant- level environment management orientation: the influence of management views and plant characteristics. Production and Operation Management, 10(3), 257-275. https://doi.org/10.1111/j.19375956.2001.tb00374.x

Kleindorfer, P.R., Singhal, K., \& Wassenhove, L.N. (2005). Sustainable Operations Management. Production and Operations Management, 14(4), 482-492. https://doi.org/10.1111/j.1937-5956.2005.tb00235.x

Kosko, B. (1986). Fuzzy Cognitive Maps. International Journal on Man-Machine Studies, 24, 65-75. https://doi.org/10.1016/S0020-7373(86)80040-2

Kosko, B. (1988). Adaptive bi-directional associative memories. IEEE Trans. Srst Mancybern, 18(1), 49-60.

Lambert, D.M., \& Cooper, M.C. (2000). Issues in supply chain management. Industrial Marketing Management, 29(1), 65-83. https://doi.org/10.1016/S0019-8501(99)00113-3

Lehtonen, M. (2004). The Environmental- social interface of sustainable development capabilities, social capital, institutions. Ecological Economics, 49(2), 199-214. https://doi.org/10.1016/j.ecolecon.2004.03.019

Lin, C., Choy, K.L., Ho, G.T.S., Chung, S.H., \& Lam, H.Y. (2015). Survey of Green Vehicle Routing Problem: Past and future trends. Expert Systems with Applications, 41(4), 1118-1138. https://doi.org/10.1016/j.eswa.2013.07.107

Lin, Y., Shi, Y., \& Zhou, L. (2010). Service Supply Chain: Nature, Evolution, and Operational Implications. In Huang, G, Mak, K.L., \& Maropoulos, P. (Eds.), Proceedings of the 6th CIRP-Sponsored International Conference on Digital Enterprise Technology (66, 1189-1204). Springer Berlin Heidelberg. https://doi.org/10.1007/978-3-642-10430-5_91

Liu, W., Bai E., Liu, L., \& Wei, W. (2017). A Framework of Sustainable Service Supply Chain Management: A Literature Review and Research Agenda. Journal of sustainability, 9(3), 421. https://doi.org/10.3390/su9030421

Mayyas, A., Qattawi, A., Omar, M., \& Shan, D. (2012). Design for sustainability in automotive industry: a comprehensive review. Renew Sustain Energy Rev, 16, 1845-62. https://doi.org/10.1016/j.rser.2012.01.012

McGain, F., \& Naylor, C. (2014). Environmental sustainability in hospitals - a systematic review and research agenda. Journal of Health Services Research \& Policy, 19(4), 245-252. https://doi.org/10.1177/1355819614534836

Neves, A.R., \& Leal, V. (2010). Energy sustainability indicators for local energy planning: Review of current practices and derivation of a new framework. Renew Sustain Energy Rev, 14, 2723-2735. https://doi.org/10.1016/j.rser.2010.07.067

Rogriguez-Repiso, L., Setchi, R., \& Salmeron, J.L. (2007). Modelling IT Projects Success with Fuzzy Cognitive Maps. Expert Systems with Applications, 32(2), 543-559. https://doi.org/10.1016/j.eswa.2006.01.032

Rumelt, R.P. (1974). Strategy, Structure, and Economic Performance. Cambridge, MA: Harvard University Press.

Sampson, S.E., \& Froehle, C.M. (2006). Foundations and implications of a proposed unified services theory. Production and Operations Management, 15(2), 329-343. https://doi.org/10.1111/j.1937-5956.2006.tb00248.x

Sampson, S.E., \& Spring, M. (2012). Customer roles in service supply chains and opportunities for innovation. J. Supply Chain Manag., 48, 30-50. https://doi.org/10.1111/j.1745-493X.2012.03282.x

Samuel, C., Gonapa, K., Chaudhary, P.K., \& Mishra, A. (2010). Supply chain dynamics in healthcare services. International Journal of Health Care Quality Assurance, 23(7), 631-642. https://doi.org/10.1108/09526861011071562

Schneider, M., Shnaider, E., Kandel, A., \& Chew, G. (1998). Automatic Construction of FCMs. Fursy Sets and Systems, 93, 161-172. https://doi.org/10.1016/S0165-0114(96)00218-7

Sengupta, K., Heiser, D.R., \& Cook, L.S. (2006). Manufacturing and Service Supply Chain Performance: A Comparative Analysis. J Supply Chain Manag, 42, 4-15. https://doi.org/10.1111/j.1745-493X.2006.00018.x

Seuring, S., \& Müller, M. (2008). Core issues in sustainable supply chain management - a Delphi study. Business Strategy and the Environment, 17(8), 455-466. https://doi.org/10.1002/bse.607

Sundarakani, B., De Souza, R., Goh, M., Wagner, S.M., \& Manikandan, S. (2010). Modeling carbon footprints across the supply chain. Int J Prod Econ, 128, 43-50. https://doi.org/10.1016/j.ijpe.2010.01.018 
Surana, A., Kumara, S., Greaves, M., \& Raghavan, N. (2005). Supply chain networks: a complex adaptive system perspective. International Journal of Production Research, 43(20), 4235-4265.

https://doi.org/10.1080/00207540500142274

Szmidt, E., \& Kacprzyk, J. (2000). Distances between intuitionistic fuzzy sets. Fuz:y Sets and Systems, 114(3), 505-518. https://doi.org/10.1016/S0165-0114(98)00244-9

Teuteberg, F., \& Wittstruck D. (2010). A systematic review of sustainable supply chain management research: What is there and what is missing? Betriebliches Umwelt- und Nachbaltigkeitsmanagement, 1001-1015.

Touboulic, A., \& Walker, H. (2015). Theories in sustainable supply chain management: a structured literature review. International Journal of Physical Distribution \& Logistics Management, 45(1/2). https://doi.org/10.1108/IJPDLM-05-20130106

Truffer, C.J. (2010). Health Spending Projections Through 2019: The Recession Continues. Health Affairs Journal, 29(3), 522-529. https://doi.org/10.1377/hlthaff.2009.1074

Tseng, M.-L., Lim, M., Wong, W.-P., Chen, Y.-C., \& Zhan, Y. (2016). A framework for evaluating the performance of sustainable service supply chain management under uncertainty. International Journal of Production Economics, 195, 359-372. https://doi.org/10.1016/j.ijpe.2016.09.002

Van Ark, B., Mahony, M., \& Timmer, M.P. (2008). The productivity gap between Europe and the United States: trends and causes. Journal of Economic Perspectives, 22(1), 25-44. https://doi.org/10.1257/jep.22.1.25

Wang, Y.L., Wallace, S.W., Shen, B., \& Choi, T.M. (2015). Service supply chain management: A review of operational models. Eur J Oper Res, 247, 685-698. https://doi.org/10.1016/j.ejor.2015.05.053

WCED (1987). Our Common Future, World Commission on Environment and Development. Oxford: Oxford University Press.

Willard, B. (2002). The Sustainability Advantage: Seven Business Case Benefits of a Triple Bottom Line. Gabriola Island, BC: New Society Publishers.

Wittstruck, D., \& Teuteberg, F. (2011). Understanding the success factors of sustainable supply chain management: Empirical evidence from the electrics and electronics industry. Corporate Social Responsibility and Environmental Management, 19(3). 141-158. https://doi.org/10.1002/csr.261

Xu. Z., \& Cai, X. (2012). Intuitionistic Fuzzy Information Aggregation: Theory and Applications. Science Press Springer, 1-102

Zadeh, L.A. (1965). Fuzzy sets. Information and Control, 8, 338-353. https://doi.org/10.1016/S0019-9958(65)90241-X

Zailani, S., Jeyaraman, K., Vengadasan, G., \& Premkumar, R. (2012). Sustainable supply chain management (SSCM) in Malaysia: A survey. International Journal of Production Economics, 140, 330-340.

https://doi.org/10.1016/j.ijpe.2012.02.008

Zhang, Q., Jiang, S., Jia, B., \& Luo, S. (2010). Some information measures for interval-valued intuitionistic fuzzy sets. Information science, 180(24), 5130-5145. https://doi.org/10.1016/j.ins.2010.08.038

Zhou, M., Park, T., \& Yi, J. (2009). Commonalities and Differences between Service and Manufacturing Supply Chains: Combining Operations Management Studies with Supply Chain Management. Calif J Oper Manag, 7, 136-143.

Journal of Industrial Engineering and Management, 2018 (www.jiem.org)

\section{(ब) $\Theta \Theta$}

Article's contents are provided on an Attribution-Non Commercial 4.0 Creative commons International License. Readers are allowed to copy, distribute and communicate article's contents, provided the author's and Journal of Industrial Engineering and Management's names are included. It must not be used for commercial purposes. To see the complete license contents, please visit https://creativecommons.org/licenses/by-nc/4.0/. 